\title{
Rozwój sektora rolnego w Polsce i krajach Unii Europejskiej
}

\section{Development of the Agricultural Sector in Poland and European Union Countries}

\begin{abstract}
Synopsis. Rola i znaczenie sektora rolnego ulega zmianom w procesie rozwoju społecznogospodarczego. Pomimo zachodzących zmian rolnictwo w Polsce nadal jest ważnym sektorem gospodarki, a Polska jest znaczącym producentem żywności. W artykule podjęto próbę oceny rozwoju sektora rolnego w Polsce według województw oraz w krajach Unii Europejskiej wykorzystując wskaźniki ekonomiczne. Przeprowadzono analizę dynamiki zmian w poziomie zatrudnienia i wartości dodanej brutto w ujęciu trzech sektorów. Zastosowanie do badania syntetycznej miary rozwoju umożliwiło dokonanie oceny poszczególnych województw oraz krajów Unii Europejskiej z punktu widzenia rozwoju sektora rolnego. Badanie wykazało, że w ostatnich latach rola sektora rolnego w Polsce i krajach Unii Europejskiej uległa zmniejszeniu. Poza tym zaobserwowano duże zróżnicowanie w rozwoju rolnictwa w układzie województw oraz w krajach Unii Europejskiej.
\end{abstract}

Słowa kluczowe: sektor rolny, syntetyczny miernik rozwoju

\begin{abstract}
The role and importance of the agricultural sector is changing in the process of socioeconomic development. Despite the ongoing changes, agriculture in Poland is still an important sector of the economy, and Poland is a major producer of food. The article attempts to assess the development of the agricultural sector in Poland, by voivodships and in comparison with European Union countries, using economic indicators. An analysis of the dynamics of changes in the level of employment and gross value added in terms of three sectors was carried out. Application to the synthetic measure of development made it possible to assess individual voivodships and EU countries from the point of view of the development of the agricultural sector. The research has shown that in recent years the role of the agricultural sector in Poland and European Union countries has decreased. In addition, there was a large variation in the development of agriculture in the system of provinces and in the countries of the European Union.
\end{abstract}

Key words: agricultural sector, synthetic development measure

JEL Classification: C38, Q10

\section{Wprowadzenie}

W ostatnich latach zarówno w Polsce jak i większości rozwiniętych gospodarek obserwujemy spadek liczby zatrudnionych w rolnictwie oraz wzrost zatrudnienia w sektorze usług. Według danych podanych przez Główny Urząd Statystyczny (GUS) w II kwartale 2017 roku, w rolnictwie pracowało 1726 tys. osób. W 2016 r. w porównaniu z rokiem poprzednim nastąił wzrost globalnej produkcji rolniczej o 7,1\%, który był wynikiem wzrostu produkcji roślinnej (o 10,3\%) oraz produkcji zwierzęcej (o 3,8\%)

${ }^{1}$ dr hab., Katedra Metod Statystycznych, Wydział Ekonomiczno-Socjologiczny UŁ, ul. Rewolucji 1905 r. nr 41, 90-214 Łódź, e-mail: agata@korespondencja.eu, https://orcid.org/0000-0003-3525-5604 
(Rolnictwo w 2016, 2017). Celem artykułu jest przedstawienie rozwoju sektora rolnego na tle innych sektorów gospodarki oraz zwrócenie uwagi na rozwój rolnictwa w układzie województw i krajów Unii Europejskiej. Badania dowodzą, że ocena rozwoju sektora rolnego powinna być przeprowadzana $\mathrm{w}$ trzech przekrojach, tzn. poprzez porównania trójsektorowe, regionalne i międzynarodowe, ze względu na wartość dodaną brutto oraz poziom zatrudnienia. Złożoność procesu rozwoju, na który wpływa wiele zmiennych wymagało zastosowania odpowiednich metod statystycznych. W pierwszej części artykułu poświęconej polskiemu rolnictwu analizie poddano, liczbę pracujących oraz wartość dodaną brutto w latach 1994-2015. Do tego celu wykorzystano wskaźniki struktury i indeksy dynamiki. $\mathrm{W}$ badaniach nad rozwojem regionów brak jest jednego uniwersalnego miernika określającego poziom rozwoju, w związku z tym do dalszej analizy wykorzystano miarę rozwoju Hellwiga. W drugiej części artykułu analizie poddano rozwój sektora rolnego w krajach Unii Europejskiej.

\section{Sektor rolny w Polsce na tle innych sektorów}

Podział gospodarki na trzy sektory niejednokrotnie budzi pewne uwagi na temat braku ostrości podziału sektorów i przenikania sektora usług do pozostałych sektorów, podział taki pozwala jednak na uchwycenie pewnych zmian dokonujących się w strukturze gospodarki. Polska gospodarka znajduje się w stanie, w którym działalność produkcyjna i działalność usługowa współistnieją obok siebie, warunkują swój rozwój i wzajemnie się przenikają. Rozwój w literaturze przedmiotu jest określany jako długotrwały proces kierunkowych zmian, w którym można wyodrębnić prawidłowo po sobie następujące etapy przemian, wykazujące zróżnicowanie pod względem określonych cech. Chojnicki (1989) rozwój określa jako ciąg zmian o długotrwałym charakterze składający się z faz, stadiów i etapów. Karpiński (1986) uważa, że im głębsze są zmiany struktury, tym szybsze jest tempo rozwoju. Czerwińska (2003) twierdzi, że „tempo wzrostu gospodarczego jest uwarunkowane taką strukturą gospodarki, w której duży jest udział dziedzin dynamizujących gospodarkę: w krótkim okresie dzięki działaniu czynników popytowych (wewnętrznych i zewnętrznych), w długim okresie - poprzez wysoki udział gałęzi o najwyższej technice i technologii wytwarzania”. Do właściwego rozwoju sektora rolnego wymagany jest odpowiedni poziom rozwoju społeczno-gospodarczego. Im wyższy jest poziom rozwoju $\mathrm{w}$ danym kraju, tym korzystniejsze występują warunki dla rozwoju rolnictwa (Tomczak, 2000). Polskie rolnictwo charakteryzuje się dużym rozdrobnieniem gospodarstw. Niecałe 30\% użytków rolnych należy do gospodarstw większych obszarowo (powyżej 50 ha), przy czym w wielu krajach Unii Europejskiej udział ten wynosi powyżej $80 \%$. Faktem jest, że w ostatnim okresie ubyło gospodarstw najmniejszych o powierzchni od 1 do 10 ha na rzecz gospodarstw o powierzchni 30 ha i więcej. Miernikiem pozwalającym określić strukturę gospodarki jest zatrudnienie. Sektorowa struktura zatrudnienia odzwierciedla dojrzałość gospodarki. W tabeli 1 przedstawiono strukturę pracujących według trzech sektorów gospodarki w latach 1994-2015.

W analizowanym okresie obserwujemy istotne zmiany w liczbie osób pracujących w gospodarce. Od roku 1994 do 2003 zatrudnienie w rolnictwie wykazywało pewną stabilizację. Od momentu przystapienia Polski do Unii Europejskiej udział zatrudnienia w sektorze rolnym spadł o około 10 punktów procentowych. Według Wilkin i Nurzyńskiej (2016) w ogólnej liczbie zatrudnionych w kraju, pracujący w rolnictwie stanowią 11,5\% 
i jest to najwyższy wskaźnik wśród krajów Europejskich. W sektorze usług udział pracujących sukcesywnie wzrasta, w roku 2003 przekroczył 50\% i nadal rośnie. Zmniejszenie udziału zatrudnionych $\mathrm{w}$ rolnictwie $\mathrm{i}$ wzrost zatrudnienia $\mathrm{w}$ usługach jest uznawany za symptom rozwoju gospodarki. Uważa się, że wzrost zatrudnienia w usługach jest charakterystyczny dla kraju, w którym mieszkańcy osiagnęli już pewien poziom dochodów i następuje wzrost podaży i popytu na coraz bardziej nowoczesne usługi. W sektorze przemysłowym także obserwujemy tendencję spadku zatrudnienia, ale miała ona charakter powolny i stopniowy, a zachodzące zmiany nie były tak istotne jak, w dwóch pozostałych sektorach. W celu określenia rozmiarów i kierunków rozwoju (zmian w czasie) badanego zjawiska wykorzystano indeksy dynamiki. W tabeli 2 przedstawiono dynamikę pracujących według sektorów gospodarki.

Tabela 1. Trójsektorowa struktura pracujących w Polsce

Table 1. Three-sector structure working in Poland

\begin{tabular}{|c|c|c|c|c|c|c|c|}
\hline Rok & $\begin{array}{c}\text { Pracujący } \\
\text { (w tys.) }\end{array}$ & $\begin{array}{l}\text { Sektor } \\
\text { rolniczy } \\
\text { (w tys.) }\end{array}$ & $\begin{array}{l}\text { Udział \% } \\
\text { sektora } \\
\text { rolniczego }\end{array}$ & $\begin{array}{l}\text { Sektor } \\
\text { przemys. } \\
\text { (w tys.) }\end{array}$ & $\begin{array}{l}\text { Udział \% } \\
\text { sektora } \\
\text { przemys. }\end{array}$ & $\begin{array}{l}\text { Sektor } \\
\text { usługowy } \\
\text { (w tys) }\end{array}$ & $\begin{array}{c}\text { Udział \% } \\
\text { sektora } \\
\text { usługowego }\end{array}$ \\
\hline 1994 & 14924,0 & 4054,4 & 27,17 & 4570,0 & 30,62 & 6299,6 & 42,21 \\
\hline 1995 & 15129,1 & 4207,1 & 27,81 & 4556,2 & 30,12 & 6365,8 & 42,08 \\
\hline 1996 & 15487,4 & 4371,5 & 28,23 & 4626,0 & 29,86 & 6489,9 & 41,90 \\
\hline 1997 & 15940,8 & 4377,9 & 27,46 & 4708,8 & 29,54 & 6854,1 & 43,00 \\
\hline 1998 & 15921,1 & 4356,1 & 27,36 & 4588,6 & 28,82 & 6976,4 & 43,81 \\
\hline 1999 & 16008,9 & 4334,0 & 27,07 & 4341,6 & 27,12 & 7016,1 & 43,83 \\
\hline 2000 & 15488,8 & 4314,9 & 27,86 & 3949,0 & 25,50 & 7224,9 & 46,65 \\
\hline 2001 & 14995,6 & 4296,8 & 28,65 & 3700,7 & 24,68 & 6998,1 & 46,67 \\
\hline 2002 & 14923,7 & 4287,8 & 28,73 & 3564,5 & 23,88 & 7071,4 & 47,38 \\
\hline 2003 & 12640,7 & 2144,6 & 16,96 & 3488,9 & 27,60 & 7007,2 & 55,43 \\
\hline 2004 & 12720,2 & 2145,1 & 16,86 & 3519,7 & 27,67 & 7055,4 & 55,46 \\
\hline 2005 & 12890,7 & 2134,1 & 16,56 & 3519,1 & 27,30 & 7237,5 & 56,15 \\
\hline 2006 & 13220,0 & 2134,6 & 16,15 & 3684,9 & 27,87 & 7400,5 & 55,98 \\
\hline 2007 & 13771,1 & 2138,2 & 15,53 & 3907,7 & 28,38 & 7725,2 & 56,10 \\
\hline 2008 & 14037,2 & 2128,3 & 15,16 & 3938,7 & 28,06 & 7970,2 & 56,78 \\
\hline 2009 & 13782,3 & 2124,9 & 15,42 & 3774,5 & 27,39 & 7882,9 & 57,20 \\
\hline 2010 & 14106,9 & 2376,1 & 16,84 & 3774,7 & 26,76 & 7956,1 & 56,40 \\
\hline 2011 & 14145,0 & 2375,5 & 16,79 & 3801,4 & 26,87 & 7968,1 & 56,33 \\
\hline 2012 & 14172,0 & 2378,0 & 16,78 & 2867,8 & 20,24 & 8940,6 & 63,09 \\
\hline 2013 & 14244,3 & 2379,0 & 16,70 & 2872,2 & 20,16 & 8926,2 & 62,67 \\
\hline 2014 & 14563,4 & 2384,9 & 16,38 & 2955,7 & 20,30 & 8993,1 & 61,75 \\
\hline 2015 & 14829,8 & 2384,8 & 16,08 & 3003,8 & 20,26 & 9222,8 & 62,19 \\
\hline
\end{tabular}

Źródło: obliczenia własne na postawie Rocznika Statystycznego Rzeczypospolitej Polskiej 1997, 2000, 2001, 2005, 2008, 2011, 2013, 2016 
Tabela 2. Dynamika pracujących według sektorów gospodarki

Table 2. Dynamics of employment by economic sectors

\begin{tabular}{|c|c|c|c|c|c|c|c|c|c|}
\hline Rok & $\begin{array}{l}\text { Sektor } \\
\text { rolniczy } \\
\text { (w tys.) }\end{array}$ & $\begin{array}{c}\text { rok } \\
\text { poprzedni } \\
=100\end{array}$ & $1994=100$ & $\begin{array}{c}\text { Sektor } \\
\text { przemys. } \\
\text { (w tys.) }\end{array}$ & $\begin{array}{c}\text { rok } \\
\text { poprzedni } \\
=100\end{array}$ & $1994=100$ & $\begin{array}{l}\text { Sektor } \\
\text { usługowy } \\
\text { (w tys.) }\end{array}$ & $\begin{array}{c}\text { rok } \\
\text { poprzedni } \\
=100\end{array}$ & $1994=100$ \\
\hline 1994 & 4054 & - & - & 4570 & - & - & 6300 & - & - \\
\hline 1995 & 4207 & 103,8 & 103,8 & 4556 & 99,7 & 99,7 & 6366 & 101,1 & 101,1 \\
\hline 1996 & 4372 & 103,9 & 107,8 & 4626 & 101,5 & 101,2 & 6490 & 101,9 & 103,0 \\
\hline 1997 & 4378 & 100,1 & 108,0 & 4709 & 101,8 & 103,0 & 6854 & 105,6 & 108,8 \\
\hline 1998 & 4356 & 99,5 & 107,4 & 4589 & 97,4 & 100,4 & 6976 & 101,8 & 110,7 \\
\hline 1999 & 4334 & 99,5 & 106,9 & 4342 & 94,6 & 95,0 & 7016 & 100,6 & 111,4 \\
\hline 2000 & 4315 & 99,6 & 106,4 & 3949 & 91,0 & 86,4 & 7225 & 103,0 & 114,7 \\
\hline 2001 & 4297 & 99,6 & 106,0 & 3701 & 93,7 & 81,0 & 6998 & 96,9 & 111,1 \\
\hline 2002 & 4288 & 99,8 & 105,8 & 3565 & 96,3 & 78,0 & 7071 & 101,0 & 112,3 \\
\hline 2003 & 2145 & 50,0 & 52,9 & 3489 & 97,9 & 76,3 & 7007 & 99,1 & 111,2 \\
\hline 2004 & 2145 & 100,0 & 52,9 & 3520 & 100,9 & 77,0 & 7055 & 100,7 & 112,0 \\
\hline 2005 & 2134 & 99,5 & 52,6 & 3519 & 100,0 & 77,0 & 7238 & 102,6 & 114,9 \\
\hline 2006 & 2135 & 100,0 & 52,6 & 3685 & 104,7 & 80,6 & 7401 & 102,3 & 117,5 \\
\hline 2007 & 2138 & 100,2 & 52,7 & 3908 & 106,0 & 85,5 & 7725 & 104,4 & 122,6 \\
\hline 2008 & 2128 & 99,5 & 52,5 & 3939 & 100,8 & 86,2 & 7970 & 103,2 & 126,5 \\
\hline 2009 & 2125 & 99,8 & 52,4 & 3775 & 95,8 & 82,6 & 7883 & 98,9 & 125,1 \\
\hline 2010 & 2376 & 111,8 & 58,6 & 3775 & 100,0 & 82,6 & 7956 & 100,9 & 126,3 \\
\hline 2011 & 2376 & 100,0 & 58,6 & 3801 & 100,7 & 83,2 & 7968 & 100,2 & 126,5 \\
\hline 2012 & 2378 & 100,1 & 58,7 & 2868 & 75,4 & 62,8 & 8941 & 112,2 & 141,9 \\
\hline 2013 & 2379 & 100,0 & 58,7 & 2872 & 100,2 & 62,8 & 8926 & 99,8 & 141,7 \\
\hline 2014 & 2385 & 100,2 & 58,8 & 2956 & 102,9 & 64,7 & 8993 & 100,7 & 142,8 \\
\hline 2015 & 2385 & 100,0 & 58,8 & 3004 & 101,6 & 65,7 & 9223 & 102,6 & 146,4 \\
\hline
\end{tabular}

Źródło: obliczenia własne na postawie Rocznika Statystycznego Rzeczypospolitej Polskiej 1997, 2000, 2001, 2005, 2008, 2011, 2013, 2016.

Zastosowanie do badania indeksów dynamiki pozwoliło na ocenę zachodzących zmian w liczbie pracujących w trzech sektorach gospodarki w latach 1994-2015. Na szczególną uwagę zasługują zmiany jakie miały miejsce w sektorze rolnym w latach 1998-2005, w których to z roku na rok obserwujemy spadek liczby pracujących. Porównując kolejne lata z rokiem 1994 miał miejsce znaczny spadek pracujących w sektorze rolnym. Na uwage zasługuje także sektor usług, w którym w przeciwieństwie do sektora rolnego obserwujemy ciaggły wzrost pracujących.

Ważnym wskaźnikiem w ocenie rozwoju gospodarki w ujęciu sektorowym jest wartość dodana brutto. Udział rolnictwa w wartości dodanej brutto w 2015 roku kształtował się poniżej 3\%. Zmniejszający się poziom tego wskaźnika świadczy o malejącym znaczeniu rolnictwa w gospodarce Polski. Malejący udział rolnictwa w wartości dodanej brutto jest konsekwencją przeobrażeń strukturalnych. Obserwujemy przy tym szybkie tempo wzrostu udziału wartości dodanej brutto w sektorze usług. Podobnie wygląda udział sektora w tworzeniu PKB. „Spadający udział rolnictwa w tworzeniu PKB 
jest konsekwencją przeobrażeń strukturalnych i szybszego tempa wzrostu działów pozarolniczych w gospodarce narodowej. Świadczy to o ewolucji w kierunku do nowoczesnej struktury gospodarki narodowej” (Mrówczyńska-Kamińska, 2008). W tabeli 3 przedstawiono strukturę wartości dodanej brutto według trzech sektorów.

Tabela 3. Struktura wartości dodanej brutto według sektorów gospodarki

Table 3 . Gross value added structure by sector

\begin{tabular}{|c|c|c|c|c|c|c|c|}
\hline Rok & $\begin{array}{c}\text { Wartość } \\
\text { dodana brutto } \\
\text { ogółem }\end{array}$ & $\begin{array}{l}\text { Sektor } \\
\text { rolniczy }\end{array}$ & $\begin{array}{c}\text { Udział \% } \\
\text { sektora } \\
\text { rolniczego }\end{array}$ & $\begin{array}{c}\text { Sektor } \\
\text { przemys. }\end{array}$ & $\begin{array}{c}\text { Udział \% } \\
\text { sektora } \\
\text { przemys. }\end{array}$ & $\begin{array}{c}\text { Sektor } \\
\text { usługowy }\end{array}$ & $\begin{array}{c}\text { Udział \% } \\
\text { sektora } \\
\text { usługowego }\end{array}$ \\
\hline 1994 & 179716 & 13353 & 7,43 & 71564 & 39,82 & 94799 & 52,75 \\
\hline 1995 & 268289 & 18560 & 6,92 & 104467 & 38,94 & 145262 & 54,14 \\
\hline 1996 & 336854 & 21646 & 6,43 & 126332 & 37,50 & 188876 & 56,07 \\
\hline 1997 & 412870 & 22771 & 5,52 & 153794 & 37,25 & 236305 & 57,23 \\
\hline 1998 & 485177 & 23097 & 4,76 & 175952 & 36,27 & 278411 & 57,38 \\
\hline 1999 & 535829 & 20991 & 3,92 & 192306 & 35,89 & 323268 & 60,33 \\
\hline 2000 & 662468 & 32832 & 4,96 & 209975 & 31,70 & 419661 & 63,35 \\
\hline 2001 & 694896 & 35459 & 5,10 & 204854 & 29,48 & 454583 & 65,42 \\
\hline 2002 & 714353 & 32300 & 4,52 & 205135 & 28,72 & 476918 & 66,76 \\
\hline 2003 & 743321 & 32699 & 4,40 & 220035 & 29,60 & 490587 & 66,00 \\
\hline 2004 & 816515 & 41720 & 5,11 & 252475 & 30,92 & 522320 & 63,97 \\
\hline 2005 & 866329 & 39235 & 4,53 & 266043 & 30,71 & 561051 & 64,76 \\
\hline 2006 & 931179 & 39930 & 4,29 & 289680 & 31,11 & 601569 & 64,60 \\
\hline 2007 & 1027631 & 44514 & 4,33 & 327176 & 31,84 & 655941 & 63,83 \\
\hline 2008 & 1116476 & 41698 & 3,73 & 352109 & 31,54 & 722669 & 64,73 \\
\hline 2009 & 1193982 & 43513 & 3,64 & 379227 & 31,76 & 771242 & 64,59 \\
\hline 2010 & 1246427 & 46905 & 3,76 & 398644 & 31,98 & 800879 & 64,25 \\
\hline 2011 & 1338990 & 48260 & 3,60 & 446516 & 33,35 & 844273 & 63,05 \\
\hline 2012 & 1412909 & 55103 & 3,90 & 348121 & 24,64 & 1009685 & 71,46 \\
\hline 2013 & 1470844 & 47602 & 3,24 & 366052 & 24,89 & 1057190 & 71,88 \\
\hline 2014 & 1524940 & 44939 & 2,95 & 386652 & 25,36 & 1093349 & 71,70 \\
\hline 2015 & 1595276 & 41514 & 2,60 & 419646 & 26,31 & 1134116 & 71,09 \\
\hline
\end{tabular}

Źródło: obliczenia własne na postawie Rocznika Statystycznego Rzeczypospolitej Polskiej 1997, 2000, 2001, 2005, 2008, 2011, 2013, 2016.

Zmiany zachodzące $\mathrm{w}$ wartości dodanej brutto według sektorów gospodarki przedstawiono $\mathrm{w}$ tabeli 4 . 
Tabela 4. Dynamika wartości dodanej brutto według sektorów gospodarki

Table 4. Growth of gross value added by sectors of economy

\begin{tabular}{|c|c|c|c|c|c|c|c|c|c|}
\hline Rok & $\begin{array}{l}\text { Sektor } \\
\text { rolniczy }\end{array}$ & $\begin{array}{c}\text { rok } \\
\text { poprzedni } \\
=100\end{array}$ & $1994=100$ & $\begin{array}{c}\text { Sektor } \\
\text { przemys. }\end{array}$ & $\begin{array}{c}\text { rok } \\
\text { poprzedni } \\
=100\end{array}$ & $1994=100$ & $\begin{array}{l}\text { Sektor } \\
\text { usług }\end{array}$ & $\begin{array}{l}\text { rok } \\
\text { poprzedni } \\
=100\end{array}$ & $1994=100$ \\
\hline 1994 & 13353 & - & - & 71564 & - & - & 94799 & - & - \\
\hline 1995 & 18560 & 139,0 & 139,0 & 104467 & 146,0 & 146,0 & 145262 & 153,2 & 153,2 \\
\hline 1996 & 21646 & 116,6 & 162,1 & 126332 & 120,9 & 176,5 & 188876 & 130,0 & 199,2 \\
\hline 1997 & 22771 & 105,2 & 170,5 & 153794 & 121,7 & 214,9 & 236305 & 125,1 & 249,3 \\
\hline 1998 & 23097 & 101,4 & 173,0 & 175952 & 114,4 & 245,9 & 278411 & 117,8 & 293,7 \\
\hline 1999 & 20991 & 90,9 & 157,2 & 192306 & 109,3 & 268,7 & 323268 & 116,1 & 341,0 \\
\hline 2000 & 32832 & 156,4 & 245,9 & 209975 & 109,2 & 293,4 & 419661 & 129,8 & 442,7 \\
\hline 2001 & 35459 & 108,0 & 265,6 & 204854 & 97,6 & 286,3 & 454583 & 108,3 & 479,5 \\
\hline 2002 & 32300 & 91,1 & 241,9 & 205135 & 100,1 & 286,6 & 476918 & 104,9 & 503,1 \\
\hline 2003 & 32699 & 101,2 & 244,9 & 220035 & 107,3 & 307,5 & 490587 & 102,9 & 517,5 \\
\hline 2004 & 41720 & 127,6 & 312,4 & 252475 & 114,7 & 352,8 & 522320 & 106,5 & 551,0 \\
\hline 2005 & 39235 & 94,0 & 293,8 & 266043 & 105,4 & 371,8 & 561051 & 107,4 & 591,8 \\
\hline 2006 & 39930 & 101,8 & 299,0 & 289680 & 108,9 & 404,8 & 601569 & 107,2 & 634,6 \\
\hline 2007 & 44514 & 111,5 & 333,4 & 327176 & 112,9 & 457,2 & 655941 & 109,0 & 691,9 \\
\hline 2008 & 41698 & 93,7 & 312,3 & 352109 & 107,6 & 492,0 & 722669 & 110,2 & 762,3 \\
\hline 2009 & 43513 & 104,4 & 325,9 & 379227 & 107,7 & 529,9 & 771242 & 106,7 & 813,6 \\
\hline 2010 & 46905 & 107,8 & 351,3 & 398644 & 105,1 & 557,0 & 800879 & 103,8 & 844,8 \\
\hline 2011 & 48260 & 102,9 & 361,4 & 446516 & 112,0 & 623,9 & 844273 & 105,4 & 890,6 \\
\hline 2012 & 55103 & 114,2 & 412,7 & 348121 & 78,0 & 486,4 & 1009685 & 119,6 & 1065,1 \\
\hline 2013 & 47602 & 86,4 & 356,5 & 366052 & 105,2 & 511,5 & 1057190 & 104,7 & 1115,2 \\
\hline 2014 & 44939 & 94,4 & 336,6 & 386652 & 105,6 & 540,3 & 1093349 & 103,4 & 1153,3 \\
\hline 2015 & 41514 & 92,4 & 310,9 & 419646 & 108,5 & 586,4 & 1134116 & 103,7 & 1196,3 \\
\hline
\end{tabular}

Źródło: obliczenia własne na postawie Rocznika Statystycznego Rzeczypospolitej Polskiej 1997, 2000, 2001, 2005, 2008, 2011, 2013, 2016.

Wraz z rozwojem społeczno-gospodarczym następował spadek udziału zatrudnienia w rolnictwie w zatrudnieniu ogółem oraz wartości dodanej brutto. Istnieje wiele wskaźników, które są wykorzystywane w ocenie rozwoju i znaczenia sektora rolnego w gospodarce. Do wskaźników tych obok wspomnianej wartości dodanej brutto i liczby zatrudnionych można zaliczyć: produkcję globalną ogółem, wartość brutto środków trwałych, nakłady inwestycyjne, przeciętne miesięczne wynagrodzenie i wiele innych. Ze względu na wielocechowość analizowanego zjawiska w dalszej części badania wykorzystano syntetyczną miarę rozwoju. Umożliwiła ona porządkowanie badanych obiektów (województw, krajów) ze względu na poziom rozwoju sektora rolnego, którego nie da się zmierzyć jedną miarą. 


\section{Syntetyczny Miernik Rozwoju}

Rozwój regionu jest kategorią mierzalną, nie mniej jednak ze względu na złożony charakter zjawisk społeczno-gospodarczych, występujących w procesach rozwoju poszczególnych regionów jest trudny do wyrażenia za pomocą jednego miernika. Wymagane jest więc stosowanie różnych mierników odzwierciedlających wszystkie istotne cechy, pozwalające na dokonanie oceny badanego regionu (Szymala, 2000). Syntetyczny miernik rozwoju (SMR) wykorzystuje się do liniowego porządkowania obiektów opisanych przez wiele zmiennych diagnostycznych (Pluta 1986), które zastępowane są przez jedną zmienną syntetyczną.

Konstrukcja syntetycznego miernika rozwoju przebiega etapowo:

1. normalizacja wartości zmiennych diagnostycznych $\left(\mathrm{x}_{\mathrm{ij}}\right)$;

2. utworzenie wzorca, czyli obiektu, który posiada najkorzystniejsze wartości zmiennych diagnostycznych $\left(z_{0 j}=\max _{i}\left\{z_{i j}\right\}\right.$, gdzie $z_{i j}$ wartości znormalizowane), jakie zostały zaobserwowane w całym zbiorze danych;

3. wyznaczenie odległości $\left(d_{i}\right)$ każdego obiektu od zbudowanego wzorca.

$$
d_{i}=\sqrt{\frac{1}{m} \sum_{j=1}^{m}\left(z_{i j}-z_{0 j}\right)^{2}}
$$

gdzie:

$\mathrm{i}=1, \ldots . ., \mathrm{n}-$ liczba obiektów;

$\mathrm{j}=1, . ., \mathrm{m}-$ liczba zmiennych;

$z_{i j}$ - znormalizowana wartość $\mathrm{j}$ - tej zmiennej dla i - tego obiektu, $z_{i j}=\frac{x_{i j}-\bar{x}_{j}}{S_{k}}$

$z_{0 j}$ - wzorcowa znormalizowana wartość j - tej zmiennej.

Normalizację miernika przeprowadza się według następującej formuły:

$$
z_{i}=1-\frac{d_{i}}{d_{0}}
$$

gdzie:

$z_{i}$-syntetyczny miernik rozwoju dla i-tego obiektu,

$d_{0}$ - norma zapewniająca przyjmowanie przez $z_{i}$ wartości należące do przedziału od 0 do 1 , którą można wyznaczyć np. jako wartość maksymalną $d_{i}$ :

$$
d_{0}=\max _{i}\left\{d_{i}\right\}
$$

Większe wartości miernika wskazują na wyższy poziom rozwoju badanego zjawiska.

\section{Wyniki badania}

W celu oceny poziomu rozwoju sektora rolnego w Polsce i krajach Unii Europejskiej zastosowano syntetyczny miernik rozwoju. Do badania wykorzystano następujące zmienne:

$\mathrm{X}_{1}$ - produkcja globalna ogółem, 
$\mathrm{X}_{2}$ - wartość brutto środków trwałych ogółem w mln zł;

$\mathrm{X}_{3}$ - pracujący w rolnictwie;

$\mathrm{X}_{4}$ - wartość skupu produktów rolnych na 1 ha użytków rolnych;

$\mathrm{X}_{5^{-}}$nakłady inwestycyjne na 1 ha użytków rolnych w zł;

$\mathrm{X}_{6}$ - powierzchnia użytków rolnych ogółem $\mathrm{w}$ tys. ha;

$\mathrm{X}_{7-}$ przeciętne miesięczne wynagrodzenia w rolnictwie;

$\mathrm{X}_{8}$ - wartość dodana brutto $\mathrm{w}$ mln zł.

Wybór zmiennych był podyktowany dostępnością danych oraz ich dużym znaczeniem w rozwoju sektora rolnego.

Tabela 5. Wartości syntetycznego miernika rozwoju

Table 5. The value of the synthetic development measure

\begin{tabular}{c|lc}
\hline Lp. & \multicolumn{1}{|c}{ Województwo } & SMR \\
\hline 1 & Mazowieckie & 0,46 \\
2 & Wielkopolskie & 0,38 \\
3 & Podlaskie & 0,28 \\
4 & Lódzkie & 0,26 \\
5 & Lubelskie & 0,20 \\
6 & Małopolskie & 0,18 \\
7 & Warmińsko-mazurskie & 0,15 \\
8 & Kujawsko-pomorskie & 0,14 \\
9 & Pomorskie & 0,11 \\
10 & Śląskie & 0,10 \\
11 & Dolnośląskie & 0,10 \\
12 & Świętokrzyskie & 0,05 \\
13 & Opolskie & 0,04 \\
14 & Zachodniopomorskie & 0,03 \\
15 & Lubuskie & 0,02 \\
16 & Podkarpackie & 0,00 \\
\hline
\end{tabular}

Źródło: obliczenia własne.

Na podstawie przeprowadzonego badania zostały wyodrębnione cztery grupy województw:

grupa $\mathrm{A} z_{i} \geq \overline{\mathrm{z}}+S_{\mathrm{z}}$

grupa $\mathrm{B} \overline{\mathrm{z}}+S_{\mathrm{z}}>z_{i} \geq \overline{\mathrm{z}}$

grupa $\mathrm{C} \overline{\mathrm{z}}>z_{i} \geq \overline{\mathrm{z}}-S_{\mathrm{z}}$

grupa $\mathrm{D} z_{i}<\overline{\mathrm{z}}-S_{\mathrm{z}}$

Do grupy A zostały zaliczone województwa o najwyższym poziomie rozwoju sektora rolnego natomiast do grupy B województwa charakteryzujące się najniższym poziomem rozwoju.

gdzie:

$z_{i}$-wartość miernika syntetycznego,

$\overline{z_{i}}-$ średnia arytmetyczna cechy (wskaźnika syntetycznego) $z_{i}$,

$s_{z}$ - odchylenie standardowe cechy $z_{i}$. 
Tabela 6. Przynależność województw do klasy rozwoju $\left(\overline{z_{i}}=0,15 ; s_{\mathrm{z}}=0,12\right)$

Table 6. Belonging to a class of development regions $\left(\overline{z_{i}}=0,15 ; s_{\mathrm{z}}=0,12\right)$

\begin{tabular}{c|cl}
\hline Klasa & Kryterium przynależności do klasy & Przynależność województwa \\
\hline A & $z_{i}>0,27$ & mazowieckie, wielkopolskie, podlaskie \\
B & $0,27>z_{i} \geq 0,15$ & łódzkie, lubelskie, małopolskie, warmińsko-mazurskie \\
C & $0,15>z_{i} \geq 0,03$ & kujawsko-pomorskie, pomorskie, śląskie, dolnośląskie, \\
D & $z_{i}<0,03$ & świętokrzyskie, opolskie, zachodniopomorskie \\
\hline
\end{tabular}

Źródło: obliczenia własne.

Rozwój rolnictwa w układzie województw jest bardzo zróżnicowany, badanie wykazało znaczne dysproporcje. Do grupy województw o najwyższym poziomie rozwoju zostało zaliczone województwo: mazowieckie, wielkopolskie i podlaskie. Województwa lubuskie i podkarpackie zostały zakwalifikowane do klasy D, o najniższym poziomie rozwoju. Pozostałe województwa należą do klasy B i C charakteryzują się przeciętnym i mniej niż przeciętnym poziomem rozwoju sektora rolnego. Województwa należące do klasy A charakteryzują się największą powierzchnią użytków rolnych. Udział województwa wielkopolskiego w produkcji globalnej w 2015 r. wynosił 16,6\%, mazowieckiego 15,8\% natomiast w przypadku województwa lubuskiego i podkarpackiego było to $2,3 \%$. Trzy województwa zaliczone do klasy A dominowały także pod względem udziału wartości brutto środków trwałych w sektorze rolnym. Podobnie wyglądał udział tych województw w tworzeniu wartości dodanej brutto. Nakłady inwestycyjne także były najwyższe w tych województwach, w województwie wielkopolskim wynosiły 926,9 mln zł, mazowieckim $818,8 \mathrm{mln}$. zł, a podlaskim $392,7 \mathrm{mln}$ zł. Duże dysproporcje zostały zaobserwowane w zasobach środków trwałych, jest to czynnik, który miał decydujące znaczenie w podziale województw na określone grupy rozwoju. Najwyższy udział środków trwałych wystapił w województwie: małopolskim, mazowieckim, wielkopolskim, lubelskim i podlaskim. Województwa zaliczone do klasy B charakteryzują się dość niskim poziomem zatrudnienia (do 10 osób na 100 ha), wyjątkiem jest województwo małopolskie.

Tabela 7. Wartości syntetycznego miernika rozwoju w krajach Unii Europejskiej

Table 7. The value of the synthetic development measure in the European Union countries

\begin{tabular}{c|lc|c|lc}
\hline Lp. & \multicolumn{1}{|c|}{ Kraj } & SMR & Lp. & \multicolumn{1}{|c}{ Kraj } & SMR \\
\hline 1 & Niemcy & 0,46 & 15 & Bułgaria & 0,11 \\
2 & Francja & 0,43 & 16 & Grecja & 0,11 \\
3 & Wielka Brytania & 0,30 & 17 & Litwa & 0,11 \\
4 & Hiszpania & 0,29 & 18 & Cypr & 0,11 \\
5 & Włochy & 0,24 & 19 & Szwecja & 0,11 \\
6 & Malta & 0,23 & 20 & Finlandia & 0,10 \\
7 & Holandia & 0,18 & 21 & Słowacja & 0,10 \\
8 & Belgia & 0,17 & 22 & Polska & 0,09 \\
9 & Dania & 0,16 & 23 & Austria & 0,08 \\
10 & Luksemburg & 0,16 & 24 & Portugalia & 0,07 \\
11 & Węgry & 0,15 & 25 & Lotwa & 0,07 \\
12 & Irlandia & 0,15 & 26 & Słowenia & 0,07 \\
13 & Czechy & 0,14 & 27 & Estonia & 0,05 \\
14 & Chorwacja & 0,13 & 28 & Rumunia & 0,00 \\
\hline
\end{tabular}

Źródło: obliczenia własne. 
W toku dalszych analiz badaniu poddano rozwój sektora rolnego w krajach Unii Europejskiej. W przypadku rozwoju sektora rolnego duże znaczenie mają warunki klimatyczne, które nie są jednolite w całej Europie. Analiza raportów i danych statystycznych pozwala stwierdzić, że najlepsze warunki panują w krajach „starej” Unii Europejskiej, w których ludność rolnicza stanowi niewielki odsetek, a proces wytwarzania żywności jest silnie zmechanizowany. Gospodarka rolna w tych krajach przyjmuje intensywny charakter to znaczy, że przy wysokich nakładach uzyskiwane są wysokie wyniki. Wśród krajów tych przoduje Dania, Holandia i Belgia. Ważnym czynnikiem wpływającym na opłacalność produkcji rolniczej jest system dopłat bezpośrednich z Unii Europejskiej. Udział ludności aktywnej zawodowo w rolnictwie dla UE 28 w 2005 roku stanowił 2,6\% ogółu ludności aktywnej zawodowo, w 2014 r. było to 1,9\%. Do państw o najniższym poziomie zatrudnienia w rolnictwie w 2014 r. należały: Słowenia (0,2\%), Malta (0,5\%), Belgia (0,5\%), Luksemburg $(0.6 \%)$, Wielka Brytania $(0,7 \%)$, Niemcy $(0,7 \%)$, Francja $(0, \& \%)$ i Holandia $(1,1 \%)$. Najwyższy poziom ludności aktywnej zawodowo w rolnictwie wśród krajów Unii Europejskiej w 2014 r. utrzymywał się w Polsce (6,9\%), Grecji (4,8\%) i na Łotwie (4,7\%). Analizując poziom zatrudnienia w dłuższym okresie czasu obserwujemy tendencję spadkowa. Jest to $\mathrm{w}$ dużej mierze konsekwencją rozwoju mechanizacji, która sprawia, że zaangażowanie człowieka w prace rolne jest coraz mniejsze. W krajach UE stopa wzrostu realnego PKB także była bardzo zróżnicowana, zarówno na przestrzeni czasu, jak i między państwami członkowskimi. Udział rolnictwa UE28 w strukturze PKB w 2015 roku wyniósł 2,2\%, w 2010 było to 2,1\%, a w 2006 3,2\%. Największy udział w PKB ma rolnictwo w krajach uznawanych za biedniejsze. Na uwagę zasługuje również wskaźnik wydajności, który w okresie ostatnich dziesięciu lat wykazuje wzrost i dla sektora rolnictwa, leśnictwa i rybactwa wynosi $28,0 \%$. W przypadku wartości dodanej brutto najwyższe wartości zaobserwowano na Węgrze (4,5\%), w Bułgarii (4,4\%), Rumunii (4,3\%), Chorwacji (4,0\%) i Grecji (4,0\%). Zróżnicowany poziom analizowanych wskaźników sprawił, że do badania rozwoju sektora rolnego w krajach Unii Europejskiej także wykorzystano syntetyczny miernik rozwoju. W badaniu oparto się na następujących zmiennych:

$\mathrm{X} 1$ - powierzchnia użytków rolnych w $\mathrm{mln}$;

X2- zużycie nawozów mineralnych na 1 ha użytków rolnych;

$\mathrm{X} 3$ - pracujący w rolnictwie $\mathrm{w}$ tys.;

X4- wartość dodana brutto;

X5- nakłady pracy w rolnictwie;

X6- wartość produkcji w mln euro.

Wybór zmiennych tak jak we wcześniejszym badaniu był związany z dostępnością danych statystycznych. Wartości syntetycznego miernika rozwoju przedstawiono w tabeli 7.

Tabela 8. Przynależność krajów Unii Europejskiej do klasy rozwoju $\left(\overline{\mathrm{z}}=0,16 ; s_{\mathrm{z}}=0,10\right)$

Table 8. Countries belonging to the development class $\left(\bar{z}=0,16 ; s_{\mathrm{z}}=0,10\right)$

\begin{tabular}{c|cl}
\hline Klasa & $\begin{array}{c}\text { Kryterium przynależności } \\
\text { do klasy }\end{array}$ & \multicolumn{1}{c}{ Przynależność krajów Unii Europejskiej } \\
\hline $\mathrm{A}$ & $z_{i}>0,26$ & Niemcy, Francja, Wielka Brytania, Hiszpania \\
$\mathrm{B}$ & $0,26>z_{i} \geq 0,16$ & Włochy, Malta, Holandia, Belgia, Dania, Luksemburg \\
$\mathrm{C}$ & $0,16>z_{i} \geq 0,06$ & Węgry, Irlandia, Czechy, Chorwacja, Bułgaria, Gracja, Litwa, Cypr, Szwecja, \\
$\mathrm{D}$ & $z_{i}<0,03$ & Finlandia, Słowacja, Polska, Austria, Portugalia, Lotwa, Słowenia \\
\hline
\end{tabular}

Źródło: obliczenia własne. 
Na podstawie otrzymanych wyników dokonano podziału analizowanych krajów na cztery klasy rozwoju sektora rolnego - tabela 8 .

Zastosowanie syntetycznej miary rozwoju potwierdziło wcześniejsze przypuszczenia co do rozwoju poszczególnych krajów. Do grupy krajów o najwyższym poziomie rozwoju zaliczono: Niemcy, Francję Wielką Brytanię i Hiszpanię. Francja jest uważana za potęga rolniczą w Europie, jej udział w produkcji rolnej UE wynosi 18,1\%. Swą produkcją rolną Francja wyprzedza Niemcy $(13,4 \%)$, Włochy $(12,3 \%)$ i Hiszpanię $(10,6 \%)$, (https://pl.ambafrance.org/Francja-glowna-potega-rolnicza-w). W rolnictwie, w Wielkiej Brytanii jest zatrudnionych około $2 \%$ ludności, ale odsetek ten jest w stanie zaspokoić około 50\% potrzeb żywnościowych mieszkańców tego kraju. Należy podkreślić, że w Wielkiej Brytanii przeważają średnie i duże gospodarstwa rolne (średnia wielkość 72,6 ha), które cechuje wysoki poziom mechanizacji. Udział rolnictwa większości krajów w strukturze gospodarczej oraz zatrudnieniu jest nadal bardzo wysoki. Z roku na rok następuje zmniejszenie podstawowych wskaźników obrazujących znaczenie rolnictwa dla gospodarki. Należy jednak zauważyć, że duży wpływ na taką sytuację ma postęp technologiczny, który z kolei wpływa na wydajność produkcji rolnej. Według raportu „World Agriculture: Towards 2015/2030” Organizacji Żywności i Rolnictwa przy Organizacji Krajów Zjednoczonych (FAO) na świecie obserwuje się spadek produkcji rolnej oraz zmniejszanie terenów uprawnych. W raporcie jest podkreślone, że sytuacja taka nie jest wynikiem braku wody czy terenów pod rozwój rolnictwa, lecz słabnącego popytu na produkty rolnicze (http://ppg.ibngr.pl/pomorski-przeglad-gospodarczy/kondycja-ikierunki-rozwoju-swiatowego-rolnictwa).

\section{Podsumowanie}

Sektor rolny ze względu na to, że zapewnia pożywienie i daje pracę jest potocznie uważany za najważniejszy sektor gospodarki. W zdecydowanej mierze na rozwój tego sektora wpływają warunki naturalne oraz nakłady finansowe. Rolnictwo polskie charakteryzuje się dużym zróżnicowaniem struktury agrarnej oraz niską produktywnością pracy (około 30\% przeciętnego poziomu w rolnictwie UE-28). Pomimo tendencji spadkowej w porównaniu z krajami Unii Europejskiej w Polsce w przeliczeniu na 100 ha utrzymuje się wysoki poziom zatrudnienia. W ostatnich latach nastąpiła poprawa dochodów ludności rolniczej, niemniej jednak ponad $60 \%$ mieszkańców wsi żyje w skrajnym ubóstwie. Według „Raportu o stanie wsi. Polska wieś 2016” w 2014 r. poniżej minimum egzystencji żyło w Polsce $7,4 \%$ ludności kraju, a na wsi było to $11,8 \%$. Najwyższy poziom ubóstwa występuje w województwie warmińsko-mazurskim i świętokrzyskim. W analizie rozwoju sektora rolnego pominięto poziom wykształcenia, który także wpływa na rozwój sektora. W 2002 r. wykształcenie wyższe rolnicze posiadało 1,1\% kierujących gospodarstwem, w 2010 nastąpił wzrost do 2\%. W układzie województw różnice pomiędzy poziomem wykształcenia rolników nie są duże i zbliżone do struktury dla kraju (por. Głębocki, 2014). Analiza danych dotyczących pracujących i wartość i dodanej brutto w układzie sektorowym pozwala stwierdzić, że znacznie zmniejszył się udział sektora rolniczego zarówno w wartości dodanej brutto jak i liczbie pracujących. Zmniejszająca się liczba pracujących w rolnictwie jest jedną z prawidłowości przekształceń strukturalnych w gospodarce. W wyniku przeprowadzonego badania wyodrębniono cztery klasy rozwoju sektora rolnego i zaobserwowano znaczne dysproporcje w rozwoju 
województw. Analiza danych pozwala stwierdzić, że intensywny rozwój polskiego rolnictwa nastąpił $\mathrm{w}$ momencie przystąpienia do Unii Europejskiej. W celu dalszego rozwoju sektora rolnego konieczne jest podejmowanie działań w kierunku poprawy konkurencyjności i zwiększenia poziomu dochodów. Uważa się, że dalsze zmiany w rozwoju polskiego rolnictwa będą szły w kierunku zmian, obserwowanych w krajach, w których rozwój rolnictwa jest na wysokim poziomie, wynika to z Wspólnej Polityki Rolnej państw członkowskich. Zastosowanie syntetycznej miary rozwoju do analizy rozwoju krajów europejskich pozwoliło na wyodrębnienie krajów charakteryzujących się podobnym poziomem rozwoju sektora rolnego. Badanie pokazało, że w przypadku sektora rolnego istnieje podział na kraje Europy Zachodniej oraz Środkowej i Wschodniej. Polska znalazła się w grupie krajów o przeciętnym poziomie rozwoju rolnictwa.

\section{Literatura}

Chojnicki, Z. (1989). Podstawowe aspekty rozwoju społeczno-gospodarczego (Basic aspects of socio-economic development). W: Współczesne problemy gospodarki przestrzennej polski, red. Kukliński A., UW, Warszawa.

Czerwińska, E. (2003). Usługi w gospodarce polskiej (Services in the Polish economy). Biuro Studiów i Ekspertyz, Informacja nr 99.1.

Głębocki, B. (2014). Zróżnicowanie przestrzenne rolnictwa (Spatial diversification of agriculture). Powszechny Spis Rolny 2010, Zakład Wydawnictw Statystycznych, Warszawa.

Karpiński, A. (1986). Restrukturyzacja gospodarki w Polsce i na świecie (Restructuring of the economy in Poland and in the world). PWE, Warszawa.

Mrówczyńska-Kamińska, A. (2008). Znaczenie rolnictwa w gospodarce narodowej w Polsce, analiza makroekonomiczna i regionalna (Importance of agriculture in the national economy in Poland, macroeconomic and regional analysis). Zeszyty Naukowe SGGW Problemy Rolnictwa Światowego 5(20), 96-107.

Pluta, W. (1986). Wielowymiarowa analiza porównawcza w modelowaniu ekonometrycznym (Multidimensional comparative analysis in econometric modeling). PWN, Warszawa.

Rocznik Statystyczny Rzeczypospolitej Polskiej (Statistical Yearbook of the Republic of Poland) 1997, 2000, 2001, 2005, 2008, 2011, 2013, 2016. Wyd. GUS, Warszawa.

Rolnictwo w 2016 r. (Agriculture in 2016). (2017). Wyd. GUS, Warszawa.

Szymala, Z. (2000). Determinanty rozwoju regionalnego (Determinants of regional development). Wyd. Zakład Narodowy im. Ossolińskich, Wrocław.

Tomczak, F. (2000). Rozwój rolnictwa światowego. Uwarunkowania i konsekwencje dochodowe (Development of world agriculture. Conditions and income consequences). IERiGŻ, Warszawa

Wilkin, J., Nurzyńska, I. (2016). Polska wieś 2016. Raport o stanie wsi (Poland. Village 2016. Report on the state of the village). Wyd. SCHOLAR, Warszawa.

http://ppg.ibngr.pl/pomorski-przeglad-gospodarczy/kondycja-i-kierunki-rozwoju-swiatowego-rolnictwa.

https://pl.ambafrance.org/Francja-glowna-potega-rolnicza-w.

Do cytowania / For citation:

Szczukocka A. (2018). Rozwój sektora rolnego w Polsce i krajach Unii Europejskiej. Problemy Rolnictwa Światowego, 18(1), 275-286; DOI: 10.22630/PRS.2018.18.1.25

Szczukocka A. (2018). Development of the Agricultural Sector in Poland and European Union Countries (in Polish). Problems of World Agriculture, 18(1), 275-286;

DOI: $10.22630 /$ PRS.2018.18.1.25 